\title{
Contribution of blood platelets to vascular pathology in Alzheimer's disease
}

\author{
This article was published in the following Dove Press journal: \\ Journal of Blood Medicine \\ 7 November 2013 \\ Number of times this article has been viewed
}

\author{
Wei Zhang ${ }^{1,2}$ \\ Wei Huang' \\ Fang Jing' \\ 'Department of Pharmacology, \\ Institutes for Advanced \\ Interdisciplinary Research, East \\ China Normal University, Shanghai, \\ People's Republic of China; \\ ${ }^{2}$ Shanghai Engineering Research \\ Center of Molecular Therapy and \\ Pharmaceutical Innovation, Shanghai, \\ People's Republic of China
}

\begin{abstract}
Cerebral amyloid angiopathy (CAA) is a critical factor in the pathogenesis of Alzheimer's disease (AD). In the clinical setting, nearly $98 \%$ AD patients have CAA, and $75 \%$ of these patients are rated as severe CAA. It is characterized by the deposition of the $\beta$-amyloid peptide (mainly $\mathrm{A} \beta 40$ ) in the walls of cerebral vessels, which induces the degeneration of vessel wall components, reduces cerebral blood flow, and aggravates cognitive decline. Platelets are anuclear cell fragments from bone marrow megakaryocytes and their function in hemostasis and thrombosis has long been recognized. Recently, increasing evidence suggests that platelet activation can also mediate the onset and development of CAA. First, platelet activation and adhesion to a vessel wall is the initial step of vascular injury. Activated platelets contribute to more than $90 \%$ circulating $\mathrm{A} \beta$ (mainly $\mathrm{A} \beta 1-40$ ), which in turn activates platelets and results in the vicious cycle of $A \beta$ overproduction in damaged vessel. Second, the uncontrolled activation of platelets leads to a chronic inflammatory reaction by secretion of chemokines (eg, platelet factor 4 [PF4], regulated upon activation normal T-cell expressed and presumably secreted [RANTES], and macrophage inflammatory protein [MIP-1 $\alpha]$ ), interleukins (IL-1 $\beta$, IL-7, and IL-8), prostaglandins, and CD40 ligand (CD40L). The interaction of these biological response modulators with platelets, endothelial cells, and leukocytes establishes a localized inflammatory response that contributes to CAA formation. Finally, activated platelets are the upholder of fibrin clots, which are structurally abnormal and resistant to degradation in the presence of $A \beta 42$. Thus, opinion has emerged that targeting blood platelets may provide a new avenue for anti-AD therapy.
\end{abstract}

Keywords: cerebral amyloid angiopathy, A $\beta 40$, chronic inflammatory, cerebral vessel

\section{Introduction}

Platelets are anuclear cell fragments from bone marrow megakaryocytes and usually survive in the bloodstream of humans for 7-10 days. ${ }^{1}$ Besides their normal function in hemostasis, platelets play a central role in pathological thrombus formation, which is an important risk factor for Alzheimer's disease (AD) occurrence. ${ }^{2,3}$ In addition, many studies have indicated that AD patients have altered platelet function. ${ }^{4}$ Recent studies have demonstrated a close association between the degree of platelet activation and the progress of $\mathrm{AD} .{ }^{4,5}$ The purpose of this review is to provide new insights that review an association between blood platelets and $\mathrm{AD}$ vasculopathy.

\section{Platelet activation and beta-amyloid $(A \beta)$ | -40 overproduction}

The accumulation of $A \beta$ peptides (mainly $A \beta 1-40$ ) as amyloid plaque in cerebral vessels plays an important role in the severity of AD pathology. Platelet activation
Correspondence: Wei Zhang East China Normal University, 3663 North Zhongshan Road, Shanghai 200062

People's Republic of China

Tel +86 2l 32530498

$\mathrm{Fax}+862132530498$

Email wzhang@sat.ecnu.edu.cn 
Table I Major molecules involved in platelet activation

\begin{tabular}{|c|c|c|c|}
\hline $\begin{array}{l}\text { Platelet } \\
\text { ligand }\end{array}$ & Source & $\begin{array}{l}\text { Platelet } \\
\text { receptor }\end{array}$ & Function \\
\hline vWF & Plasma & GPIb-IX-V & $\begin{array}{l}\text { Mediates initial platelet } \\
\text { adhesion to damaged } \\
\text { vessel walls at high } \\
\text { shear flow }\left(>500 \mathrm{~s}^{-1}\right)\end{array}$ \\
\hline Collagen & & $\begin{array}{l}\text { GPVI } \\
\alpha 2 \beta I\end{array}$ & $\begin{array}{l}\text { Initiate platelet } \\
\text { activation }\end{array}$ \\
\hline ADP & $\begin{array}{l}\text { Platelet dense } \\
\text { granules }\end{array}$ & $\begin{array}{l}\text { P2YI } \\
\text { or P2YI2 }\end{array}$ & $\begin{array}{l}\text { Provide important } \\
\text { positive feedback loop } \\
\text { for platelet activation }\end{array}$ \\
\hline $5 \mathrm{HT}$ & $\begin{array}{l}\text { Platelet dense } \\
\text { granules }\end{array}$ & $5 \mathrm{HT} 2 \mathrm{~A}$ & \\
\hline $\mathrm{TXA}^{\mathrm{a}}$ & $\begin{array}{l}\text { COX-I-dependent } \\
\text { signaling pathway }\end{array}$ & $\mathrm{TP} \alpha$ & \\
\hline Thrombin ${ }^{a}$ & $\begin{array}{l}\text { Coagulation } \\
\text { cascade or } \\
\text { platelet } \alpha \text {-granules }\end{array}$ & PARI,4 & \\
\hline $\begin{array}{l}\text { Fibrinogen } \\
\text { or vWF }\end{array}$ & Plasma & $\alpha$ llb $\beta 3$ & $\begin{array}{l}\text { Platelet-to-platelet } \\
\text { aggregation }\end{array}$ \\
\hline
\end{tabular}

Note: aMajor pathway involved in $A \beta 40$ overproduction.

Abbreviations: ADP, adenosine diphosphate; vWF, von Willebrand factor; GP, glycoprotein; P2Y, purinoceptor; 5HT, 5-hydroxytryptamine (also known as serotonin); COX, cyclooxygenase; TXA2, thromboxane $A_{2}$; TP $\alpha$, thromboxane receptor $\alpha$; PAR, protease activated receptor; $A \beta$, beta-amyloid.

and adhesion to a vascular wall is the first step of vascular damage. There are many receptors, enzymes, and signaling molecules involved in this process (Table 1). Among them, thromboxane $\mathrm{A}_{2}$ (TXA2) synthesis and thrombin-mediated signaling pathway are regarded as the major events involved in A $\beta 1-40$ overproduction. The initial activation of platelets triggers cyclooxygenase 1 (COX-1)-induced arachidonic acid (AA) metabolism, resulting in the conversion of AA to prostaglandin $\mathrm{G}_{2} / \mathrm{H}_{2}$. The latter is subsequently converted to TXA2, which is a potent platelet activator. ${ }^{6}$ Thromboxane receptor $\alpha(\mathrm{TP} \alpha)$ is a G-protein-coupled-receptor (GPCR) that is coupled to $\mathrm{Gq}$ and $\mathrm{G}_{12 / 13}$. Binding of TXA2 with TP $\alpha$ may activate a number of intracellular pathways which enhance primary platelet activation through thrombin (the most potent known platelet activator) or collagen. Protease activated receptor 1 (PAR1) is the major human platelet receptor through which thrombin facilitates the cellular effects of platelet activation without interfering with thrombin-induced cleavage of fibrinogen. ${ }^{?}$

$A \beta$ is a 36-43 amino acid peptide. It is cleaved from the integral membrane amyloid precursor protein (APP) by $\beta$ and $\gamma$-secretases to yield $A \beta$ fragments of various lengths and a smaller C-terminal fragment (CTF $\gamma$ ). Overproduction of $\mathrm{A} \beta$ peptides, as well as the failure of their degradation by enzymes, such as neprilysin and insulin degrading enzyme, lead to their oligomerization and aggregation over time to produce senile plaques that are the main neuropathological features of AD. Unlike A $\beta 1-42$ deposited in senile plaques, the circulating $A \beta$ form contributing to perivascular amyloid plaques seen in $\mathrm{AD}$ is primarily composed of $\mathrm{A} \beta 1-40$, which accounts for $90 \%$ of total $A \beta .^{8-11}$ APP is found in platelets, and human platelets express all of the enzymes which are required to process APP into A $\beta$ peptide. Platelets are therefore regarded as the main source of circulating $A \beta$. In human platelets, the major APP isoforms are APP $770^{12}$ and APP $75,{ }^{13}$ and they can be hydrolyzed by either $\alpha$-secretases (non-amyloidogenic pathway) or $\beta$-secretases (amyloidogenic pathway) to produce secreted sAPP $\alpha$ and $A \beta$ (mainly A $\beta 1-40) .{ }^{12,13}$ Both sAPP $\alpha$ and A $\beta 1-40$ can be stored in platelet $\alpha$-granules and released upon platelet activation by thrombin or collagen. ${ }^{14-17}$ Once $A \beta 1-40$ is released from the activated platelets, it can in turn activate platelets. ${ }^{18}$ As shown in Figure 1A, A $\beta 1-40$-induced platelet activation has been linked to a specific signaling pathway that initiates with the activation of the thrombin receptor PAR1 by A $\beta$ and leads to subsequent activation of p38MAPK (mitogen-activated protein kinases) pathway, which results in the stimulation of cytosolic phospholipase A2 (cPLA2) that catalyzes the release of AA for TXA2 synthesis. ${ }^{19}$ TXA2 augments the activation of platelets and the consequent secretion of $A \beta 1$ 40 , which initiates a vicious cycle of platelet activation and A $\beta 1-40$ overproduction. ${ }^{17}$ However, whether other platelet signaling molecules or second messengers are involved in this process is still unclear. Thus, association of platelet activation and $A \beta 1-40$ overproduction may represent a mechanism whereby $A \beta 1-40$ deposition in the walls of cerebral vessels leads to angiopathy occurring in $\mathrm{AD}$.

\section{Platelet activation and proinflammatory mediator release}

Inflammatory reaction plays an important role in the pathogenesis of $\mathrm{AD}$. Platelet activation and consequent degranulation can result in the secretion of numerous biological mediators that are mainly stored in platelet $\alpha$ granules (Table 2). These mediators include chemokines, such as connective tissue-activating peptide III (CTAP-III), platelet factor 4 (PF4), regulated upon activation normal T-cell expressed and presumably secreted (RANTES), and macrophage inflammatory protein (MIP)- $1 \alpha$, interleukins (IL-1 $\beta$, IL-7, and IL-8), prostaglandins, and CD40 ligand (CD40L) ${ }^{20}$ As shown in Figure 1B, platelet-derived mediators enhance leukocyte adhesion and endothelial vicious release of proinflammatory cytokines, which induces cerebral 


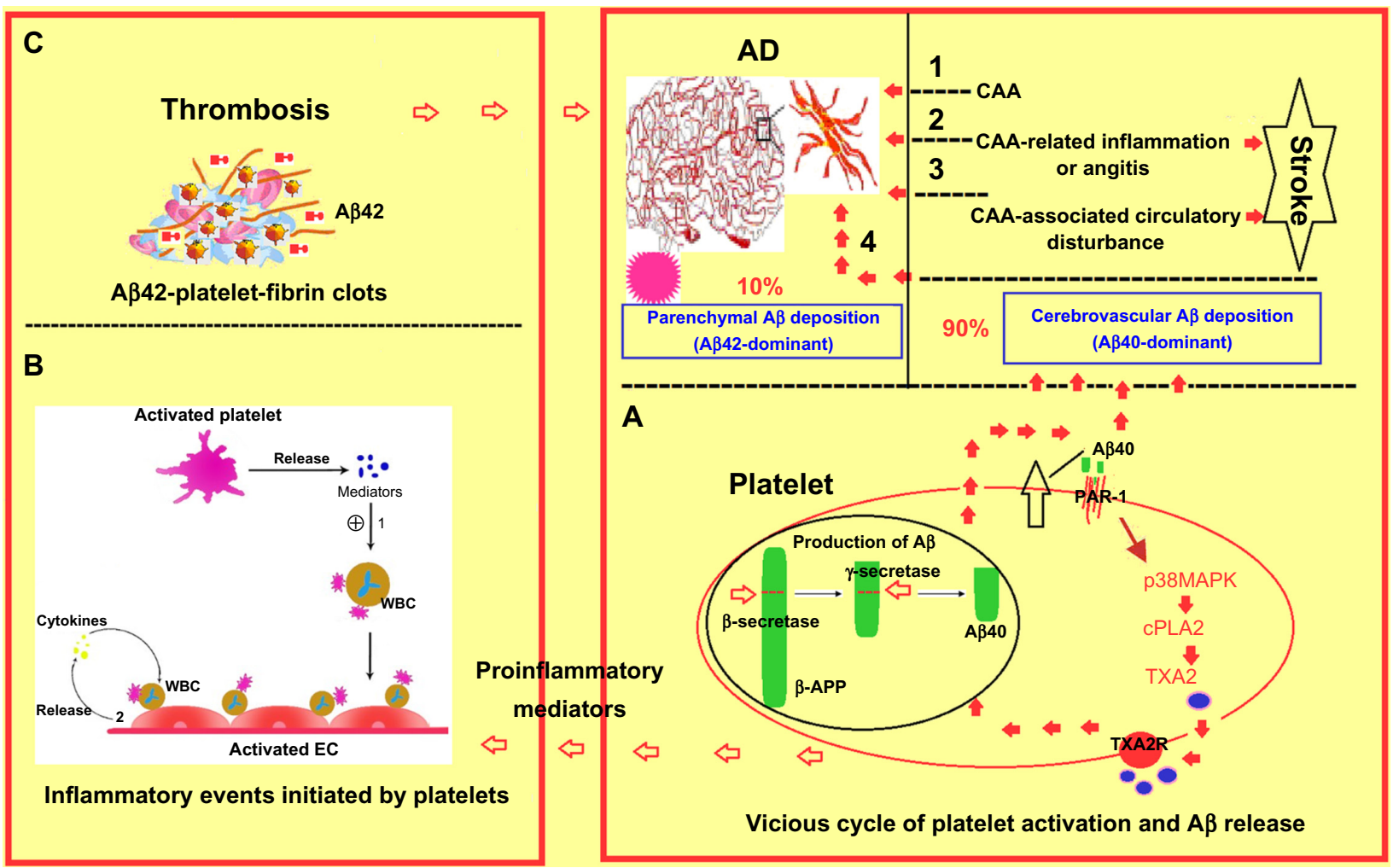

Figure I Contribution of blood platelets to vascular pathology in AD. (A) Platelet-originated A $\beta 40$ vicious cycle; (B) inflammatory events initiated by activated platelets; (C) A 342 -platelet-fibrin clot-induced thrombus formation.

Abbreviations: AD, Alzheimer's disease; CAA, cerebral amyloid angiopathy; WBC, white blood cell; EC, endothelial cell; APP, amyloid precursor protein; PAR, protease activated receptor; cPLA, cytosolic phospholipase $A$; TXA, thromboxane $A$; $A \beta$, beta-amyloid; TXA2R, thromboxane $A_{2}$ receptor.

Table 2 Key platelet biological mediators underlying Alzheimer's disease

\begin{tabular}{|c|c|c|c|c|c|}
\hline $\begin{array}{l}\text { Bioactive } \\
\text { mediators }\end{array}$ & Source & Category & Target cell & Function & Study \\
\hline $\begin{array}{l}\text { CTAP-III } \\
(\mathrm{CXCL7)}\end{array}$ & $\alpha$-granule & Chemokines & Leukocytes & $\begin{array}{l}\text { - Enhances neutrophil and monocyte } \\
\text { adhesion } \\
\text { - Promotes neutrophil transendothelial } \\
\text { migration }\end{array}$ & $\begin{array}{l}\text { Gleissner et al, } \\
\text { Brandt et al, } \\
\text { and Hundelshausen } \\
\text { and }{ }^{26}\end{array}$ \\
\hline $\begin{array}{l}\text { PF4 } \\
(\mathrm{CXCL} 4)\end{array}$ & $\alpha$-granule & Chemokines & Leukocytes & $\begin{array}{l}\text { - Cooperates with other cytokines } \\
\text { to promote leukocyte adhesion } \\
\text { and monocyte differentiation }\end{array}$ & Brandt et $\mathrm{al}^{27}$ \\
\hline $\begin{array}{l}\text { RANTES } \\
\text { (CCL5) }\end{array}$ & $\alpha$-granule & Chemokines & $\begin{array}{l}\text { Leukocytes and } \\
\text { endothelial cells }\end{array}$ & $\begin{array}{l}\text { - Promotes monocytes adhesion } \\
\text { to the endothelial cell } \\
\text { - Enhances chemokine synthesis }\end{array}$ & $\begin{array}{l}\text { Von Hundelshausen } \\
\text { et al, }{ }^{28} \text { Baltus et al, }{ }^{29} \\
\text { and Weyrich et } \text { al }^{30}\end{array}$ \\
\hline $\begin{array}{l}\text { MIP-I } \\
(\mathrm{CCL} 3)\end{array}$ & $\alpha$-granule & Chemokines & Leukocytes & $\begin{array}{l}\text { - Recruits and activates } \\
\text { polymorphonuclear leukocytes }\end{array}$ & Reichel et $\mathrm{al}^{3 !}$ \\
\hline IL-I $\beta$ & $\alpha$-granule & Cytokines & Endothelial cells & $\begin{array}{l}\text { - Upregulation of leukocyte adhesion } \\
\text { molecules (ICAM-I, } \alpha_{v} \beta_{3} \text {, and MCP-I) } \\
\text { - Stimulation of endothelial release } \\
\text { of proinflammatory cytokines }\end{array}$ & $\begin{array}{l}\text { Hawrylowicz et al, } \\
\text { Kaplanski et al, } \\
\text { Gawaz et } \text { al, }^{33} \text { and } \\
\text { Gawaz et al }{ }^{35}\end{array}$ \\
\hline $\begin{array}{l}\text { CD40L } \\
(\text { CDI54) }\end{array}$ & $\begin{array}{l}\alpha \text {-granule } \\
\text { and platelet } \\
\text { membrane }\end{array}$ & Cytokines & $\begin{array}{l}\text { Endothelial } \\
\text { cell CD40 }\end{array}$ & $\begin{array}{l}\text { - Upregulation of leukocyte adhesion } \\
\text { molecules (ICAM-I, VCAM-I, and } \\
\text { E- and P-selectin) } \\
\text { - Enhances endothelial release of } \\
\text { proinflammatory cytokines (IL-I and TF) }\end{array}$ & $\begin{array}{l}\text { Antoniades et al, } \\
\text { Kroczek et al, } \\
\text { Henn et al, }{ }^{39} \\
\text { Heeschen et al, }{ }^{40} \\
\text { and Semple et } \mathrm{al}^{41}\end{array}$ \\
\hline
\end{tabular}

Abbreviations: CTAP-III, connective tissue-activating peptide III; PF4, platelet factor 4; RANTES, regulated upon activation, normal T-cell expressed and secreted; MIP-I, macrophage inflammatory protein I; IL-I, interleukin I; CD40L, CD40 ligand; ICAM-I, intercellular adhesion molecule I; MCP-I, monocyte chemoattractant protein I; VCAM-I, vascular cell adhesion molecule I; CXCL, chemokine (C-X-C motif) ligand; TF, tissue factor; CCL, chemokine (C-C motif) ligand. 
amyloid angiopathy (CAA)-related perivascular inflammation or angitis and aggravates the reduction of cerebral blood flow and cognitive decline..$^{21-23}$

\section{Chemokines}

CTAP-III (also known as CXCL7) and PF4 (CXCL4) are chemokines with $\mathrm{C}-\mathrm{X}-\mathrm{C}$ motif, which are the two most abundant CXC chemokines stored in platelet $\alpha$ granules. CTAP-III can be hydrolyzed by the neutrophil membrane-associated serine-protease cathepsin $\mathrm{G}$ and converts into active neutrophil-activating protein (NAP)-2 that induces neutrophil and monocyte adhesion to the endothelium and neutrophil transendothelial migration. ${ }^{24-26}$ Unlike CTAP-III, PF4 needs to synergize with other cytokines, such as RANTES, to promote leukocyte adhesion and monocyte differentiation. ${ }^{27}$ RANTES is also known as chemokine (C-C motif) ligand 5 (CCL5). It is released from the $\alpha$-granules of activated platelets and deposited on activated endothelium that promotes monocytes adhesion to the endothelium and chemokine synthesis. ${ }^{28-30}$ MIP-1 $\alpha$ (or CCL3) is another chemokine found in platelet $\alpha$-granules that involves the recruitment and activation of polymorphonuclear leukocytes. ${ }^{31}$

\section{Interleukins}

IL-1 $\beta$ is a platelet-derived cytokine, playing a key role in platelet-induced endothelial activation. ${ }^{32,33}$ It induces endothelial cells to secrete IL-6 and IL-8 that results in the upregulation of intercellular adhesion molecule (ICAM)-1, $\alpha_{\mathrm{v}} \beta_{3}$, and monocyte chemotactic protein (MCP)-1, enhancing monocyte and neutrophil adhesion to the endothelium. ${ }^{33-35}$

Patel et al have characterized the cytokine expression profile in the brain of two transgenic mouse models of AD (TgAPPsw and PS1/APPsw). ${ }^{36}$ Compared with control littermates, transgenic mice showed a significant increase in the following proinflammatory cytokines: tumor necrosis factor (TNF)- $\alpha$, IL-6, IL-12p40, IL-1 $\beta$, IL-1 $\alpha$, and granulocyte-macrophage colony stimulating factor (GM-CSF). The concentrations of these inflammatory cytokines, which are likely derived from activated microglia, correlate with the level of soluble (A $\beta 1-40)$ and insoluble (A $\beta 1-42)$ forms of $A \beta$ present in the brain. This suggests that pathological accumulation of $A \beta$ is a key driver of the neuroinflammatory response.

\section{CD40L}

CD40L, also called CD154, is an important platelet-derived mediator with structural homology to the TNF superfamily. ${ }^{37}$ Although initially expressed on activated CD4 ${ }^{+} \mathrm{T}$-cells, platelet $\alpha$-granules are a rich source of CD40L and contribute to more than $95 \%$ circulating CD40L. ${ }^{38-40}$ The binding of CD40L with its endothelium surface receptor CD40 can result in upregulation of leukocyte adhesion molecules (eg, intercellular adhesion molecule-1 [ICAM-1], vascular cell adhesion molecule-1 [VCAM-1], and E- and P-selectin) and stimulation of endothelial release of proinflammatory cytokines (IL-6 and tissue factor). ${ }^{41}$ Of note, CD40-CD40L interaction is also crucial in pathogenesis of AD. Studies ${ }^{42}$ have demonstrated that in human embryonic kidney (HEK)/ APPsw, CD40wt, and the CD40-mutant cells, CD40L can increase levels of A $\beta$ (1-40), A $\beta$ (1-42), sAPP $\beta$, sAPP $\alpha$, and CTF $\beta$. Furthermore, results from CD40L treatment of a neuroblastoma cell line overexpressing the C-99 APP fragment suggest that CD40L can increase gamma-secretase activity independently of tumor necrosis factor receptor associated factor (TRAF) signaling. Thus, CD40-CD40L interaction modulates APP processing.

\section{Enhanced platelet activation in AD patients}

Platelet activation is essential in hemostasis by forming a hemostatic plug to halt hemorrhage after vascular damage. Recently, increased platelet activation has been found in AD patients (Table 3). Sevush et $\mathrm{al}^{4}$ reported that platelets of patients with $\mathrm{AD}$ exhibit greater unstimulated activation than those of controls. Potential causes of such activation include possible stimulation of platelets by damaged cerebral endothelial cells or platelet activation induced by membrane abnormalities present in platelets of patients with AD. A recent work by Ciabattoni et $\mathrm{al}^{5}$ showed a continuing potentiation of platelet activation in $\mathrm{AD}$ patients, which is relevant to increased lipid peroxidation associated with inadequate levels of vitamin E. Bermejo et $\mathrm{al}^{43}$ reported an increased platelet level of COX-2 in AD and mild cognitive impairment patients compared with elderly controls, indicating that platelet inflammatory pathways are activated, and that this could be considered an early event in AD development. Iarlori et $\mathrm{al}^{44}$ reported that higher levels of RANTES were detected in peripheral blood mononuclear cells of $\mathrm{AD}$ patients compared with control subjects and AD patients treated with donepezil. Casoli et $\mathrm{al}^{45}$ found high concentrations of MIP- $1 \alpha$ in T-cells and brain microvessels of AD patients. Coated-platelets are a recently described subset of platelets that originate upon dual stimulation of platelets with collagen and thrombin, which represents a highly pro-coagulant subset of activated platelets. ${ }^{46-48}$ A more recent study showed that elevated coated-platelet levels in patients with anamnestic 
Table 3 Enhanced platelet activation in AD patients

\begin{tabular}{|c|c|c|c|c|}
\hline Purpose & Subjects & Platelet detection index & Conclusion & Study \\
\hline $\begin{array}{l}\text { To compare baseline } \\
\text { activation of unstimulated } \\
\text { platelets in patients with AD } \\
\text { with that in control subjects }\end{array}$ & $\begin{array}{l}\text { 9I AD versus } \\
40 \text { control } \\
\text { (age-matched) }\end{array}$ & $\begin{array}{l}\text { - Percentage of circulating } \\
\text { platelet aggregates } \\
\text { - Expression of CD62P } \\
\text { - Formation of leukocyte-platelet } \\
\text { - Presence of circulating platelet } \\
\text { microparticles }\end{array}$ & $\begin{array}{l}\text { Platelets of patients } \\
\text { with } A D \text { exhibit greater } \\
\text { unstimulated activation } \\
\text { than those of controls }\end{array}$ & Sevush et $\mathrm{al}^{4}$ \\
\hline $\begin{array}{l}\text { To investigate the rate } \\
\text { of platelet TX biosynthesis } \\
\text { and its determinants in } A D\end{array}$ & $\begin{array}{l}44 \mathrm{AD} \text { versus } 44 \\
\text { matched control }\end{array}$ & $\begin{array}{l}\text { - I I-dehydro-TXB (2) and } \\
\text { 8-iso-prostaglandin F }(2 \alpha) \\
\text { (markers of in vivo platelet } \\
\text { activation and lipid } \\
\text { peroxidation, respectively) } \\
\text { - Plasma vitamin E }\end{array}$ & $\begin{array}{l}\text { Platelet activation } \\
\text { is persistently enhanced } \\
\text { in } A D \text {, which is related to } \\
\text { increased lipid peroxidation } \\
\text { associated with inadequate } \\
\text { levels of vitamin E }\end{array}$ & $\begin{array}{l}\text { Ciabattoni } \\
\text { et } \mathrm{al}^{5}\end{array}$ \\
\hline $\begin{array}{l}\text { To evaluate inflammatory } \\
\text { peripheral markers in } \mathrm{MCl} \\
\text { or } \mathrm{AD}\end{array}$ & $\begin{array}{l}34 \mathrm{MCl}, 45 \mathrm{AD} \\
\text { versus } 28 \text { control } \\
\text { (age-matched) }\end{array}$ & $\begin{array}{l}\text { - Platelet level of COX-2 } \\
\text { - IL-6 }\end{array}$ & $\begin{array}{l}\text { Inflammatory response } \\
\text { may be an early factor } \\
\text { in } A D \text { development }\end{array}$ & $\begin{array}{l}\text { Bermejo } \\
\text { et } \mathrm{al}^{43}\end{array}$ \\
\hline $\begin{array}{l}\text { To examine the possibility that } \\
\text { coated-platelet production } \\
\text { correlates with AD progression }\end{array}$ & $\begin{array}{l}40 \mathrm{AD} \\
(78.9 \pm 5.7 \text { years })\end{array}$ & - Coated-platelets & $\begin{array}{l}\text { Coated platelets correlate } \\
\text { with disease progress } \\
\text { in } A D\end{array}$ & $\begin{array}{l}\text { Dale, }{ }^{46} \text { Prodan } \\
\text { et al, }{ }^{47} \text { and } \\
\text { Prodan et } \mathrm{al}^{48}\end{array}$ \\
\hline
\end{tabular}

Abbreviations: AD, Alzheimer's disease; TX, thromboxane; $\mathrm{MCl}$, mild cognitive impairment; COX, cyclooxygenase; IL, interleukin.

mild cognitive impairment are associated with increased risk for progression to $\mathrm{AD} \cdot{ }^{47}$

\section{Epidemiology relevance of AD and stroke}

Platelets have a central role in thrombus formation. At the cellular level, thrombosis is initiated by platelets tethering to subendothelial von Willebrand factor (vWF) via the glycoprotein $\mathrm{Ib}(\mathrm{GPIb}){ }^{49-52}$ The adherent platelets become activated and co-aggregate with fibrinogen and vWF via GPIIb-IIIa. ${ }^{53-56}$ At the same time, activated platelets act as a catalytic surface for thrombin generation from its plasma pro-enzymes. ${ }^{57}$ This leads to thrombus stabilization by insoluble fibrin intermeshed within and around the platelet thrombus. The three-dimensional platelet plugs under pathophysiological conditions can obstruct circulatory system patency leading to ischemic heart disease (myocardial infarction and unstable angina), ischemic stroke, and related conditions.

A number of studies suggest that $\mathrm{AD}$ patients may have an enhanced potential for thrombosis in the circulation. Purandare et al reported that asymptomatic spontaneous cerebral emboli (SCE) were associated with the concurrent presence of clinically relevant depressive symptoms and the future rapid cognitive decline..$^{58,59}$ Brundel et al found that microinfarcts detected by conventional magnetic resonance imaging are more common in $\mathrm{AD}$ patients compared with non-demented controls. ${ }^{60}$ Schenider et al found that subcortical infarcts had an interaction with AD pathology to further worsen working memory. ${ }^{61}$ Thus, stroke may increase the risk of developing dementia; ${ }^{62} \mathrm{AD}$ patients in turn demonstrate a greater risk for stroke. ${ }^{63}$ Activated platelets are the upholder of fibrin clots. In vitro and in vivo experiments have demonstrated that fibrin clots are more difficult to degrade in the presence of $A \beta 42,{ }^{64,65}$ suggesting a mechanism by which platelets providing common adherent surface of fibrin and $A \beta$ may contribute to enhanced thrombosis (Figure 1C).

\section{Antiplatelet therapy for AD}

Antiplatelet agents are well established as treatments that can help to prevent strokes ${ }^{66}$ Aspirin, the most widely used antiplatelet agent, irreversibly inhibits platelet COX-1 activity, leading to reduced synthesis of prostaglandin and TXA2 ${ }^{67,68}$ Long-term aspirin therapy brings about a $20 \%-25 \%$ reduction in the odds of subsequent myocardial infarction, stroke, or vascular death among intermediate- or high-risk cardiovascular disease patients. ${ }^{69,70}$ Recent studies have shown that it is also an effective treatment for AD patients. ${ }^{71}$ In human studies, users of high-dose aspirin had significantly lower prevalence of $\mathrm{AD}$ and better-maintained cognitive function than nonusers. ${ }^{71}$ However, aspirin needs to be taken before the symptoms of $\mathrm{AD}$ occur. It had no effect on $\mathrm{AD}$ at a later stage when the brain damage is severe. These results suggest that repurposing existing antiplatelet drugs for the treatment of AD may be beneficial.

\section{Conclusion}

Conquering AD remains a major challenge in today's medical research due to the lack of good targets and a limited 
understanding of its pathogenesis. This review has highlighted that blood platelets have an important role in $\mathrm{AD}$ and CAA. However, there are other mechanisms, apart from platelet activation, that are emerging as important for AD progress. For example, the perivascular drainage hypothesis (ie, blockage of lymphatic drainage of the brain by CAA appears to be a significant factor in the pathogenesis of AD and other dementias and is now widely accepted as an AD risk factor). ${ }^{72}$ Nevertheless, the current review has established the concept of developing a different approach to combat AD by targeting blood platelets.

\section{Acknowledgments}

This work was supported by the National Natural Science Foundation of China (No 81170481, 81200352), Shanghai Pujiang Program (11PJ1403200), the Innovation Fund of Shanghai Municipal Education commission (12zz040), and SRF for ROCS (to WZ).

\section{Disclosure}

The authors report no conflicts of interest in this work.

\section{References}

1. Junt T, Schulze H, Chen Z, et al. Dynamic visualization of thrombopoiesis within bone marrow. Science. 2007;317(5845):1767-1770.

2. Jellinger KA. Alzheimer disease and cerebrovascular pathology: an update. J Neural Transm. 2002;109(5):813-836.

3. Jellinger KA. Prevalence and impact of cerebrovascular lesions in Alzheimer and Lewy body diseases. Neurodegener Dis. 2010;7(1-3): $112-115$.

4. Sevush S, Jy W, Horstman LL, et al. Platelet activation in Alzheimer disease. Arch Neurol. 1998;55(4):530-536.

5. Ciabattoni G, Porreca E, Di Febbo C, et al. Determinants of platelet activation in Alzheimer's disease. Neurobiol Aging. 2007;28(3): 336-342.

6. Murray R, FitzGerald GA. Regulation of thromboxane receptor activation in human platelets. Proc Natl Acad Sci U S A. 1989;86(1):124-128.

7. Coughlin SR. How the protease thrombin talks to cells. Proc Natl Acad Sci U S A. 1999;96(20):11023-11027.

8. Li QX, Berndt MC, Bush AI, et al. Membrane-associated forms of the beta A4 amyloid protein precursor of Alzheimer's disease in human platelet and brain: surface expression on the activated human platelet. Blood. 1994;84(1):133-142.

9. Chen M, Inestrosa NC, Ross GS, Fernandez HL. Platelets are the primary source of amyloid $\beta$-peptide in human blood. Biochem Biophys Res Commun. 1995;213(1):96-103.

10. Herzig MC, Winkler DT, Burgermeister $\mathrm{P}$, et al. A $\beta$ is targeted to the vasculature in a mouse model of hereditary cerebral hemorrhage with amyloidosis. Nat Neurosci. 2004;7(9):954-960.

11. Fryer JD, Holtzman DM. The bad seed in Alzheimer's disease. Neuron. 2005;47(2):167-168.

12. Bush AI, Martins RN, Rumble B, et al. The amyloid precursor protein of Alzheimer's disease is released by human platelets. J Biol Chem. 1990;265(26):15977-15983.

13. Li QX, Evin G, Small DH, Multhaup G, Beyreuther K, Masters CL. Proteolytic processing of Alzheimers disease A4 amyloid precursor protein in human platelets. J Biol Chem. 1995;270(23):14140-14147.
14. Li QX, Whyte S, Tanner JE, Evin G, Beyreuther K, Masters CL. Secretion of Alzheimer's disease Abeta amyloid peptide by activated human platelets. Lab Invest. 1998;78(4):461-469.

15. Smith CCT. Stimulated release of the $\beta$-amyloid protein of Alzheimer's disease by normal human platelets. Neurosci Lett. 1997;235(3): 157-159.

16. Evin G, Zhu A, Holsinger RM, Masters CL, Li QX. Proteolytic processing of the Alzheimer's disease amyloid precursor protein in brain and platelets. J Neurosci Res. 2003;74(3):386-392.

17. Shen MY, Hsiao G, Fong TH, et al. Amyloid beta peptide-activated signal pathways in human platelets. Eur J Pharmacol. 2008;588(2-3): 259-266.

18. Bugaud F, Nadal-Wollbold F, Lévy-Toledano S, Rosa JP, Bryckaert M. Regulation of c-jun-NH2 terminal kinase and extracellular-signal regulated kinase in human platelets. Blood. 1999;94(11):3800-3805.

19. Coulon L, Calzada C, Moulin P, Véricel E, Lagarde M. Activation of P38 mitogen-activated protein kinase/cytosolic phospholipase $\mathrm{A}_{2}$ cascade in hydroperoxide-stressed platelets. Free Radic Biol Med. 2003;35(6):616-625.

20. Klinger MHF. Platelets and inflammation. Anat embryolo. 1997; 196(1):1-11.

21. Nielsen HM, Londos E, Minthon L, Janciauskiene SM. Soluble adhesion molecules and angiotensin-converting enzyme in dementia. Neurobiol Dis. 2007;26(1):27-35.

22. Giri R, Shen Y, Stins M, et al. $\beta$-Amyloid-induced migration of monocytes across human brain endothelial cells involves RAGE and PECAM-1. Am J Physiol Cell Physiol. 2000;279(6):c1772-c1781.

23. Suo Z, Tan J, Placzek A, Crawford F, Fang C, Mullan M. Alzheimer's $\beta$-amyloid peptides induce inflammatory cascade in human vascular cells: the roles of cytokines and CD40. Brain Res. 1998;807(1-2):110-117.

24. Gleissner CA, von Hundelshausen P, Ley K. Platelet chemokines in vascular disease. Arterioscler Thromb Vasc Biol. 2008;28(11):1920-1927.

25. Brandt E, Van Damme J, Flad HD. Neutrophils can generate their activator neutrophil-activating peptide 2 by proteolytic cleavage of platelet-derived connective tissue-activating peptide III. Cytokine. 1991;3(4):311-321.

26. Hundelshausen PV, Koenen RR, Weber C. Platelet-mediated enhancement of leukocyte adhesion. Microcirculation. 2009;16(1):84-96.

27. Brandt E, Ludwig A, Petersen F, Flad HD. Platelet-derived CXC chemokines: old players in new games. Immunol Rev. 2000;177(1): 204-216.

28. Von Hundelshausen P, Weber KSC, Huo Y, et al. RANTES deposition by platelets triggers monocyte arrest on inflamed and atherosclerotic endothelium. Circulation. 2001;103(13):1772-1777.

29. Baltus T, Weber KSC, Johnson Z, Proudfoot AE, Weber C. Oligomerization of RANTES is required for CCR1-mediated arrest but not CCR5-mediated transmigration of leukocytes on inflamed endothelium. Blood. 2003;102(6):1985-1988.

30. Weyrich AS, Elstad MR, McEver RP, et al. Activated platelets signal chemokine synthesis by human monocytes. J Clin Invest. 1996;97(6): $1525-1534$.

31. Reichel CA, Rehberg M, Lerchenberger M, et al. Ccl2 and Ccl3 mediate neutrophil recruitment via induction of protein synthesis and generation of lipid mediators. Arterioscler Thromb Vasc Biol. 2009;29(11): 1787-1793.

32. Hawrylowicz CM, Howells GL, Feldmann M. Platelet-derived interleukin 1 induces human endothelial adhesion molecule expression and cytokine production. J Exp Med. 1991;174(4):785-790.

33. Kaplanski G, Farnarier C, Kaplanski S, et al. Interleukin-1 induces interleukin- 8 secretion from endothelial cells by a juxtacrine mechanism. Blood. 1994;84(12):4242-4248.

34. Gawaz M, Langer H, May AE. Platelets in inflammation and atherogenesis. J Clin Invest. 2005;115(12):3378-3384.

35. Gawaz M, Brand K, Dickfeld T, et al. Platelets induce alterations of chemotactic and adhesive properties of endothelial cells mediated through an interleukin-1-dependent mechanism. Implications for atherogenesis. Atherosclerosis. 2000;148(1):75-85. 
36. Patel NS, Paris D, Mathura V, Quadros AN, Crawford FC, Mullan MJ. Inflammatory cytokine levels correlate with amyloid load in transgenic mouse models of Alzheimer's disease. J Neuroinflammation. 2005;2(1):9.

37. Antoniades C, Bakogiannis C, Tousoulis D, Antonopoulos AS, Stefanadis C. The CD40/CD40 ligand system: linking inflammation with atherothrombosis. J Am Coll Cardiol. 2009;54(8):669-677.

38. Kroczek RA, Graf D, Brugnoni D, et al. Defective expression of CD40 ligand on T cells causes "X-linked immunodeficiency with hyper-IgM (HIGM1)". Immunol Rev. 1994;138:39-59.

39. Henn V, Slupsky JR, Grafe M, et al. CD40 ligand on activated platelets triggers an inflammatory reaction of endothelial cells. Nature. 1998;391(6667):591-593.

40. Heeschen C, Dimmeler S, Hamm CW, et al. Soluble CD40 ligand in acute coronary syndromes. $N$ Engl J Med. 2003;348(12):1104-1111.

41. Semple JW, Italiano JE, Freedman J. Platelets and the immune continuum. Nat Rev Immunol. 2011;11(4):264-274.

42. Volmar CH, Ait-Ghezala G, Frieling J, Weeks OI, Mullan MJ. CD40/ CD40L interaction induces Abeta production and increases gammasecretase activity independently of tumor necrosis factor receptor associated factor (TRAF) signaling. Exp Cell Res. 2009;315(13): 2265-2274.

43. Bermejo P, Martín-Aragón S, Benedí J, et al. Differences of peripheral inflammatory markers between mild cognitive impairment and Alzheimer's disease. Immunol Lett. 2008;117(2):198-202.

44. Iarlori C, Gambi D, Gambi F, et al. Expression and production of two selected beta-chemokines in peripheral blood mononuclear cells from patients with Alzheimer's disease. Exp Gerontol. 2005;40(7): 605-611.

45. Casoli T, Di Stefano G, Balietti M, et al. Peripheral inflammatory biomarkers of Alzheimer's disease: the role of platelets. Biogerontology. 2010;11(5):627-633.

46. Dale GL. Coated-platelets: an emerging component of the procoagulant response. J Thromb Haemost. 2005;3(10):2185-2192.

47. Prodan CI, Ross ED, Vincent AS, Dale GL. Coated-platelets correlate with disease progression in Alzheimer disease. J Neurol. 2007;254(4): 548-549.

48. Prodan CI, Ross ED, Vincent AS, Dale GL. Rate of progression in Alzheimer's disease correlates with coated-platelet levels a longitudinal study. Transl Res. 2008;152(3):99-102.

49. Ruggeri ZM, Mendolicchio GL. Adhesion mechanisms in platelet function. Circ Res. 2007;100(12):1673-1685.

50. Ruggeri ZM. Platelet adhesion under flow. Microcirculation. 2010; 16(1):58-83.

51. Savage B, Saldívar E, Ruggeri ZM. Initiation of platelet adhesion by arrest onto fibrinogen or translocation on von Willebrand factor. Cell. 1996;84(2):289-297.

52. Siediecki CA, Lestini BJ, Kottke-Marchant KK, et al. Shear-dependent changes in the three-dimensional structure of human von Willebrand factor. Blood. 1996;88(8):2939-2950.

53. Hantgan RR. Fibrin protofibril and fibrinogen binding to ADP-stimulated platelets: evidence for a common mechanism. Biochim Biophys Acta. 1988;968(1):24-35.

54. Bennett JS, Vilaire G. Exposure of platelet fibrinogen receptors by ADP and epinephrine. J Clin Invest. 1979;64(5):1393-1401.
55. Ni H, Denis CV, Subbarao S, et al. Persistence of platelet thrombus formation in arterioles of mice lacking both von Willebrand factor and fibrinogen. J Clin Invest. 2000;106(3):385-392.

56. Jackson SP. The growing complexity of platelet aggregation. Blood. 2007;109(12):5087-5095.

57. Stoll G, Kleinschnitz C, Nieswandt B. Molecular mechanisms of thrombus formation in ischemic stroke: novel insights and targets for treatment. Blood. 2008;112(9):3555-3562.

58. Purandare N, Burns A. Cerebral emboli in the genesis of dementia. J Neurol Sci. 2009;283(1):17-20.

59. Purandare N, Burns A, Morris J, et al. Association of cerebral emboli with accelerated cognitive deterioration in Alzheimer's disease and vascular dementia. Am J Psychiatry. 2012;169(3):300-308.

60. Brundel M, de Bresser J, van Dillen JJ, Kappelle LJ, Biessels GJ. Cerebral microinfarcts: a systematic review of neuropathological studies. J Cereb Blood Flow Metab. 2012;32(3):425-436.

61. Schneider JA, Boyle PA, Arvanitakis Z, Bienias JL, Bennett DA. Subcortical infarcts, Alzheimer's disease pathology, and memory function in older persons. Ann Neurol. 2007;62(1):59-66.

62. Cumming TB, Brodtmann A. Can stroke cause neurodegenerative dementia? Int J Stroke. 2011;6(5):416-424.

63. Bangen KJ, Delano-Wood L, Wierenga CE, et al. Associations between stroke risk and cognition in normal aging and Alzheimer's disease with and without depression. Int J Geriatr Psychiatry. 2009;25(2): 175-182.

64. Cortes-Canteli M, Paul J, Norris EH, et al. Fibrinogen and $\beta$-amyloid association alters thrombosis and fibrinolysis: a possible contributing factor to Alzheimer's disease. Neuron. 2010;66(5):695-709.

65. Cortes-Canteli M, Zamolodchikov D, Ahn HJ, Strickland S, Norris EH. Fibrinogen and altered hemostasis in Alzheimer's disease. J Alzheimers Dis. 2012;32:599-608.

66. Yeung J, Holinstat M. Newer agents in antiplatelet therapy: a review. J Blood Med. 2012;3:33-42.

67. Roth GJ, Stanford N, Majerus PW. Acetylation of prostaglandin synthase by aspirin. Proc Natl Acad Sci U S A. 1975;72(8):3073-3076.

68. Loll PJ, Picot D, Garavito RM. The structural basis of aspirin activity inferred from the crystal structure of inactivated prostaglandin H2 synthase. Nat Struct Biol. 1995;2(8):637-643.

69. Antithrombotic Trialists' Collaboration. Collaborative meta-analysis of randomised trials of antiplatelet therapy for prevention of death, myocardial infarction, and stroke in high risk patients. BMJ. 2002;324(7329): 71-86.

70. Patrono C, Baigent C, Hirsh J, Roth G; American College of Chest Physicians. Antiplatelet drugs: American College of Chest Physicians Evidence-Based Clinical Practice Guidelines (8th Edition). Chest. 2008;133(Suppl 6):199S-233S.

71. Bentham P, Gray R, Sellwood E, Hills R, Crome P, Raftery J; AD2000 Collaborative Group. Aspirin in Alzheimer's disease (AD2000): a randomised open-label trial. Lancet Neurol. 2008;7(1):41-49.

72. Weller RO, Djuanda E, Yow HY, Carare RO. Lymphatic drainage of the brain and the pathophysiology of neurological disease. Acta Neuropathol. 2009;117(1):1-14.

\section{Publish your work in this journal}

The Journal of Blood Medicine is an international, peer-reviewed, open access, online journal publishing laboratory, experimental and clinical aspects of all topics pertaining to blood based medicine including but not limited to: Transfusion Medicine; Blood collection, Donor issues, Transmittable diseases, and Blood banking logistics; Immunohematology; Artificial and alternative

\section{Dovepress}

blood based therapeutics; Hematology; Biotechnology/nanotechnology of blood related medicine; Legal aspects of blood medicine; Historical perspectives. The manuscript management system is completely online and includes a very quick and fair peer-review system. Visit http://www.dovepress.com/ testimonials.php to read real quotes from published authors. 